Scientiae Educatia: Jurnal Pendidikan Sains (2017), Vol 6 (2) : 87-101

DOI: http://dx.doi.org/10.24235/sc.educatia.v6i2.2000

Published by Tadris IPA Biologi, IAIN Syekh Nurjati Cirebon, Indonesia. p-ISSN: 2303-1530, e-ISSN: 2527-7596

SCIENTIAE EDUCATIA: JURNAL PENDIDIKAN SAINS

Journal homepage: www.syekhnurjati.ac.id/jurnal/index.php/sceducatia

http://www.syekhnurjati.ac.id/jurnal/index.php/sceducatia/article/view/2000

\title{
Pengaruh Pembelajaran Levels of Inquiry Terhadap Kemampuan Literasi Sains Siswa
}

\author{
Ardian Asyhari ${ }^{\mathrm{a}^{*}}$, Gita Putri Clara ${ }^{\mathrm{b}}$ \\ ${ }^{\text {ab }}$ Program Studi Pendidikan Fisika UIN Raden Intan Lampung, Lampung, 35131, Indonesia \\ *Corresponding author: Jl. Letnan Kolonel H. Endro Suratmin, Sukarame, Kota Bandar Lampung, Lampung 35131, Indonesia. E-mail \\ addresses: ardianasyhari@radenintan.ac.id
}

\section{a r t i c l e i n f o}

\section{Article history:}

Received: 11 October 2017

Received in revised form: 14

November 2017

Accepted: 14 December 2017

Available online: December 2017

Keywords:

Levels of Inquiry

Ability of Science Literacy

Archimedes Law

Kata Kunci:

Levels of Inquiry

Kemampuan Literasi Sains

Hukum Archimedes

\begin{abstract}
a b s t $\mathbf{r}$ a $\mathbf{c}$
EFFECT OF LEVELS OF INQUIRY LEARNING TOWARDS STUDENTS' SCIENCE LITERACY SKILL. This study aims to determine the effect of Levels of Inquiry learning to students' science literacy skill of class $\mathrm{X}$ on a concept of Archimedes law. This research is a quasi-experimental study with the design of the matching only pretest-posttest control group. Subjects in this study were students class X SMA Negeri 1 Baradatu $(n=72)$. The type of data produced is quantitative data. The result of this research is in conventional learning (control class), obtained mean score of science literacy skill pretest score 37,5 and mean of posttest score 48,95, while at levels of inquiry learning (experiment class), the science literacy skill obtained means of pretest score 40.97 and mean of posttest score 72.91 . Hypothesis test of science literacy skill of sig 2-tailed 0,00 because of sig $<0,05$, meaning $\mathrm{H}_{0}$ rejected $\mathrm{H}_{1}$ accepted, hence can conclude that levels of inquiry learning have significant influence to students' science literacy skill of class X in Archimedes law concept at SMA Negeri 1 Baradatu.
\end{abstract}

Penelitian ini bertujuan untuk mengetahui pengaruh pembelajaran levels of inquiry terhadap kemampuan literasi sains siswa kelas X pada materi hukum Archimedes. Penelitian ini merupakan penelitian kuasi eksperimen dengan desain the matching only pretest-posttest control group. Subjek dalam penelitian ini adalah peserta didik kelas X SMA Negeri 1 Baradatu berjumlah 72 orang peserta didik. Jenis data yang dihasilkan adalah data kuantitatif. Hasil penelitian ini adalah pada pembelajaran konvensional (kelas kontrol), diperoleh kemampuan literasi sains siswa rata-rata pretest 37,5 dan nilai rata-rata posttest 48,95, sedangkan pada pembelajaran levels of inquiry (kelas eksperimen), kemampuan literasi sains diperoleh nilai rata-rata pretest 40,97 dan nilai rata-rata posttest 72,91 . Uji hipotesis kemampuan literasi sains ditemukan nilai sig 2-tailed 0,00, karena nilai sig < 0,05 , artinya $\mathrm{H}_{0}$ ditolak $\mathrm{H}_{1}$ diterima, maka dapat disimpulkan model pembelajaran levels of inquiry berpengaruh signifikan terhadap kemampuan literasi sains siswa kelas X pada materi hukum Archimedes di SMA Negeri 1 Baradatu.

2017 Scientiae Educatia: Jurnal Pendidikan Sains

\section{Pendahuluan}

Penelitian tentang levels of inquiry (LOI) atau tingkatan inkuiri pada awalnya diperkenalkan oleh Wenning (2006; 2005; 2010; 2011) yang dapat diterapkan dalam pembelajaran dengan mempertimbangkan kondisi siswa dan guru. Pada beberapa tahun belakangan ini, penelitian tentang LOI terhitung cukup banyak dan beberapa diantaranya berfokus pada penggunaan model LOI untuk meningkatan keterampilan proses sains (Hartini,

2017; Ramdan \& Hamidah, 2015; Fatimah, Susilo, \& Diantoro, 2016; Hardianti \& 
Kuswanto, 2017), dan ada pula yang menghubungkan LOI dengan peningkatan literasi sains (Arief \& Utari, 2015; Dahtiar, 2015; Fatmawati \& Utari, 2015).

Wenning (2010) memperkenalkan LOI yang terdiri dari discovery learning, interactive demonstration, inquiry lesson, inquiry laboratory, real-world applications dan hypothetical inquiry. Tingkatan-tingkatan tersebut dibedakan menurut kecerdasan intelektual dan kontrol kelas seperti yang terdapat pada Tabel 1 .

Tabel 1. Hierarki pembelajaran sains berorientasi inquiry

\begin{tabular}{cccccc}
\hline $\begin{array}{c}\text { Discovery } \\
\text { learning }\end{array}$ & $\begin{array}{c}\text { Interactive } \\
\text { Demonstration }\end{array}$ & $\begin{array}{c}\text { Inquiry } \\
\text { lesson }\end{array}$ & $\begin{array}{c}\text { Inquiry } \\
\text { Lab }\end{array}$ & $\begin{array}{c}\text { Real world } \\
\text { applications }\end{array}$ & $\begin{array}{c}\text { Hypothetical } \\
\text { inquiry }\end{array}$ \\
\hline \multirow{2}{*}{ Rendah } & & Kecerdasan & & Tinggi \\
\cline { 2 - 3 } & & $\begin{array}{c}\text { intelektual } \\
\text { Guru }\end{array}$ & Kontrol kelas & & Siswa \\
\hline
\end{tabular}

Hierarki tersebut merupakan sebuah kerangka eksplisit yang dapat digunakan untuk pembelajaran yang berorientasi inkuiri. Wenning (2005) menerangkan bahwa hierarki tersebut dapat melatihkan kemampuan siswa secara bertahap, dari mulai berpikir tingkat dasar hingga berpikir tingkat tinggi yang juga secara bersamaan akan mengubah pusat belajar yang semula ada pada guru menjadi kepada siswa.

Penerapan pembelajaran LOI juga diharapkan dapat memperbaiki pembelajaran yang biasa dilakukan di kelas dalam mengembangkan keterampilan siswa. Kegiatan pembelajaran inkuiri yang mengikuti hierarki LOI akan terlebih dahulu melatihkan keterampilan yang lebih sederhana sebelum melatihkan keterampilan yang lebih kompleks (Wenning, 2005).

Jika mengaitkan pembelajaran LOI dengan pendidikan IPA (Fisika) saat ini yang bertujuan untuk meningkatkan kompetensi siswa agar dapat memenuhi kebutuhan hidupnya dalam berbagai situasi (Toharudin, 2011), artinya, tahapan tersebut dapat mengarahkan siswa untuk dapat menghadapi situasi saat ini secara bertahap dari berpikir rendah hingga berpikir tingkat tinggi, sehingga dengan kompetensi itu, siswa akan mampu belajar lebih lanjut dan hidup di masyarakat yang saat ini banyak dipengaruhi oleh perkembangan sains dan teknologi.

Kompetensi yang dimaksud menurut Toharudin (2011) adalah kompetensi yang terdapat pada konsep literasi sains (OECD, 2016). Konsep literasi sains dalam perkembangannya ternyata mendukung berkembangnya keterampilan berpikir tingkat tinggi (Asyhari \& Hartati, 2015; Asyhari, 2017). Dengan demikian, tujuan penelitian ini adalah untuk mengetahui 
pengaruh pembelajaran LOI terhadap kemampuan literasi sains siswa kelas X pada materi hukum Archimedes. Dari tujuan tersebut, akan diketahui apakah hierarki tertinggi dari LOI pada saat yang sama juga akan berpengaruh pada literasi sains siswa, dan akan diketahui pula apakah tiap tahapan pada hierarki tersebut mempengaruhi literasi sains siswa pada aspek konteks, kompetensi, dan pengetahuan.

Siswa yang memiliki kemampuan literasi sains dapat menumbuhkan kemampuan berpikir logis, berpikir kreatif, memecahkan masalah, bersifat kritis, menguasai teknologi, adaptif terhadap perubahan dan perkembangan zaman, serta melek sains (Carl, Cofnas, \& Woodley of Menie, 2016). Oleh karena itu, untuk menjadi orang yang melek sains maka peserta didik perlu dibekali kemampuan literasi sains. Literasi sains (science literacy) merupakan kemampuan menggunakan pengetahuan sains, mengidentifikasi pertanyaan, dan menarik kesimpulan berdasarkan bukti-bukti dalam rangka memahami dan serta membuat keputusan berkenaan dengan alam dan perubahan yang dilakukan terhadap alam melalui aktivitas manusia. Pentingnya literasi sains untuk dikuasai siswa dalam kaitannya dengan bagaimana siswa dapat memahami lingkungan hidup, kesehatan, ekonomi, dan masalah-masalah lain yang dihadapi oleh masyarakat modern yang sangat tergantung pada teknologi serta perkembangan ilmu pengetahuan (Bybee \& McCrae, 2011).

Literasi sains penting dikembangkan melalui LOI karena: (1) pemahaman terhadap sains menawarkan kepuasan dan kesenangan pribadi yang muncul setelah memahami dan mempelajari alam, (2) dalam kehidupan sehari-hari, setiap orang membutuhkan informasi dan berpikir ilmiah untuk pengambilan keputusan, (3) setiap orang perlu melibatkan kemampuan mereka dalam wacana publik dan debat mengenai isu-isu penting yang melibatkan sains dan teknologi, (4) dan literasi sains penting dalam dunia kerja, karena makin banyak pekerjaan yang membutuhkan keterampilan-keterampilan yang tinggi, sehingga mengharuskan orangorang belajar sains, bernalar, berpikir secara kreatif, membuat keputusan, dan memecahkan masalah.

\section{Metode Penelitian}

\subsection{Desain Penelitian}

Metode yang digunakan dalam penelitian ini adalah penelitian kuasi eksperimen (quasi experiment), desain yang memiliki kelompok kontrol, tetapi tidak sepenuhnya untuk mengontrol variabel-variabel luar yang mempengaruhi pelaksanaan eksperimen. Pada penelitian ini, kelas eksperimen menggunakan model pembelajaran inkuiri sedangkan kelas 
kontrol menggunakan metode pembelajaran konvensional. Dengan tipe rancangan pemasangan subjek melalui tes awal dan tes akhir dengan kelompok kontrol tipe The Matching Only Pretest-Posttest Control Group Design (Fraenkel \& Wallen, 2009). Tipe rancangan The Matching Only Pretest-Posttest Control Group Design adalah penelitian melakukan penjodohan terhadap subjek pada kelompok kontrol dan kelompok eksperimen. Dengan melakukan tes awal dan tes akhir. Rancangan ini tidak menjamin terpenuhinya ekuivalensi karena proses pemasangan tidak dilakukan secara acak (Tabel 2).

Tabel 2. The matching-only group pretest-postest control group design

\begin{tabular}{cccc}
\hline Kelas & Pretest & Treatment & Posttest \\
\hline Eksperimen & $\mathrm{O}$ & $\mathrm{X}$ & $\mathrm{O}$ \\
Kontrol & $\mathrm{O}$ & $\mathrm{C}$ & $\mathrm{O}$ \\
\hline
\end{tabular}

\subsection{Subjek Penelitian}

Populasi dalam penelitian ini adalah seluruh siswa kelas X MIA di SMA Negeri 1 Baradatu. Pada penelitian ini sampel yang digunakan adalah siswa kelas X MIA 1 dan X MIA 3 yang masing-masing berjumlah 36 siswa. Kelas X MIA 1 sebagai kelas eksperimen yang diberi perlakuan model pembelajaran inkuiri, sedangkan kelas X MIA 3 sebagai kelas kontrol menggunakan metode ceramah. Dari seluruh populasi dipilih dua kelas sebagai sampel yang dilakukan secara purposive sampling yaitu satu kelas eksperimen dengan penerapan pembelajaran levels of inquiry (LOI) dan satu kelas kontrol dengan penerapan pembelajaran konvensional.

\subsection{Instrumen Penelitian}

Instrumen yang digunakan dalam penelitian ini, yaitu berupa tes dan lembar observasi. Domain kemampuan literasi sains yang diukur pada penelitian ini terdiri dari tiga aspek, yaitu aspek pengetahuan, aspek kompetensi dan aspek konteks. Ketiga aspek ini diukur dengan menggunakan instrumen penelitian berupa soal pilihan ganda yang diadaptasi dari soal PISA 2015 dan telah dimodifikasi dan dikembangkan oleh peneliti. Instrumen ini telah melewati tahap validasi oleh 2 orang dosen ahli dan validasi item tes melalui proses uji coba yang kemudian dianalisis melalui program AnatesV4 untuk mengetahui validitas, daya beda, tingkat kesukaran soal, dan reliabilitas instrumen (Arikunto, 2013). Instrumen ini terdiri dari 8 butir soal dengan lima pilihan jawaban. Sedangkan lembar observasi untuk mengetahui keterlaksanaan model pembelajaran baik oleh siswa maupun guru. 


\subsection{Prosedur Penelitian}

Prosedur penelitian yang telah dilakukan terdiri dari tahap persiapan, pelaksanaan, dan tahap pengolahan data. Pada tahap persiapan telah dilakukan studi pendahuluan, studi kurikulum dan literatur, menyusun instrumen penelitian yang terdiri dari RPP (kelas eksperimen dengan pembelajaran LOI dan RPP kelas kontrol dengan pembelajaran konvensional), LKS, soal pretest, dan soal posttest untuk mengukur literasi sains Siswa. Pada tahap pelaksanaan telah dilakukan pemberian pretest pada kelas eksperimen dan kontrol, pemberian perlakuan sebanyak 3 kali pertemuan untuk masing-masing kelas kontrol dan eksperimen, melakukan observasi keterlaksanaan pembelajaran, dan melakukan posttest pada kelas kontrol dan eksperimen. Pada tahap pengolahan data telah dilakukan olah data hasil pretest dan posttest siswa dan menganalisis data hasil observasi.

\subsection{Analisis Data}

\subsubsection{Teknik Analisis Keterlaksanaan Model Pembelajaran}

Data yang diperoleh dari lembar observasi keterlaksanaan pembelajaran merupakan data kuantitatif yang akan dianalisis secara deskriptif persentase. Rumus yang dapat digunakan untuk mendeskripsikan keterlaksanaan pembelajaran adalah sebagai berikut:

$\mathrm{KP}(\%)=\frac{\mathrm{J}}{\mathrm{JP}} \times 100 \%$

Keterangan:

$\mathrm{KP}(\%)=$ persentase keterlaksanaan pembelajaran

$\mathrm{J}=$ jumlah aktivitas pembelajaran yang terlaksana

$\mathrm{JP} \quad=$ jumlah seluruh aktivitas pembelajaran

Selanjutnya, untuk mengetahui interpretasi dari hasil perhitungan keterlaksanaan pembelajaran tersebut, skor yang telah diperoleh (dalam bentuk \%), kemudian dikonsultasikan pada Tabel 3.

Tabel 3. Kriteria keterlaksanaan pembelajaran

\begin{tabular}{cc}
\hline Interval Persentase Keterlaksanaan Pembelajaran (KP) & Kriteria \\
\hline $\mathrm{KP}=0 \%$ & Tak satu kegiatan pun terlaksana \\
$0 \%<\mathrm{KP}<25 \%$ & Sebagian kecil kegiatan terlaksana \\
$25 \% \leq \mathrm{KP}<50 \%$ & Hampir setengah kegiatan terlaksana \\
$\mathrm{KP}=50 \%$ & Setengah kegiatan terlaksana \\
$50 \%<\mathrm{KP}<75 \%$ & Sebagian besar kegiatan terlaksana \\
$75 \% \leq \mathrm{KP}<100 \%$ & Hampir seluruh aktivitas terlaksana \\
$\mathrm{KP}=100 \%$ & Seluruh kegiatan terlaksana \\
\hline
\end{tabular}

(Muslim, 2014) 


\subsubsection{Teknik Analisis Data Hasil Tes Literasi Sains}

Untuk mengetahu peningkatan literasi sains pada kelas kontrol dan eksperimen, dilakukan perhitungan gain yang dinormalisasi ( $N$-gain, dengan simbol $\langle\mathrm{g}\rangle$ ) menggunakan persamaan sebagai berikut:

$<\mathrm{g}\rangle=\frac{\%<\mathrm{S}_{\mathrm{f}}>-\%<\mathrm{S}_{\mathrm{i}}>}{100-\%<\mathrm{S}_{\mathrm{i}}>}$

Keterangan :

$\langle\mathrm{g}\rangle=$ gain yang dinormalisasi

$\left\langle\mathrm{S}_{\mathrm{i}}\right\rangle=$ skor rata-rata tes awal (pretest)

$\left\langle\mathrm{S}_{\mathrm{f}}\right\rangle=$ skor rata-rata tes akhir (posttest)

Selanjutnya, untuk mengetahui kriteria peningkatan dari hasil perhitungan $\mathrm{N}$-gain tersebut, maka skor yang telah diperoleh kemudian dikonsultasikan pada Tabel 4.

Tabel 4. Kriteria skor rata-rata gain yang dinormalisasi

\begin{tabular}{cc}
\hline Nilai $\langle$ g $>$ & Kriteria \\
\hline$\langle\mathrm{g}>>0,7$ & Tinggi \\
$0,3<\langle\mathrm{g}>\leq 0,7$ & Sedang \\
$\langle\mathrm{g}>\leq 0,3$ & Rendah \\
\hline
\end{tabular}

\subsubsection{Pengujian Hipotesis}

Untuk melakukan uji hipotesis penelitian yang diajukan, dilakukan uji perbedaan ratarata $N$-gain kelas eksperimen dan kelas kontrol. Pengujian akan dilakukan dengan menggunakan software IBM SPSS 24. Adapun taraf signifikansi yang digunakan pada penelitian ini adalah $\alpha=0,05$.

\subsubsection{Uji Normalitas Data $N$-gain}

Uji Normalitas bertujuan untuk mengetahui sebaran distribusi data yang diperoleh. Uji normalitas yang digunakan dalam penelitian ini adalah uji Shapiro-Wilk dengan taraf signifikansi $(\alpha=0,05)$. Dalam uji normalitas, pengujian yang diajukan yaitu:

$$
\begin{aligned}
& \mathrm{H}_{0}=\text { data berdistribusi normal } \\
& \mathrm{H}_{1}=\text { data tidak berdistribusi normal }
\end{aligned}
$$

Apabila nilai sig. $>\alpha$ maka $\mathrm{H}_{0}$ diterima. Dengan kata lain bahwa data tersebut berdistribusi normal.

\subsubsection{Uji Homogenitas Varians Data $N$-gain}

Uji homogenitas dilakukan untuk melihat apakah data-data nilai yang didapat dari kedua kelompok ini memiliki kesamaan varians atau tidak. Dalam penelitian ini, uji homogenitas 
dilakukan dengan menggunakan uji Levene (Test of Homogeneity of Variances) dengan taraf signifikansi $(\alpha=0,05)$. Adapun pengujian yang diajukan sebagai berikut:

$\mathrm{H}_{0}: \sigma_{1}^{2}=\sigma_{2}^{2}$

$\mathrm{H}_{1}: \sigma_{1}^{2} \neq \sigma_{2}^{2}$

Apabila nilai dari sig. $>\alpha$ maka $\mathrm{H}_{0}$ diterima. Dengan kata lain, varians untuk kedua data tersebut adalah homogen.

\subsubsection{Uji Hipotesis}

Uji hipotesis tersebut dilakukan dengan 2 cara, yaitu:

1) Uji statistik parametrik

Uji statistik parametrik digunakan jika data memenuhi asumsi statistik, yaitu data terdistribusi normal (Furqon, 2011, hlm. 235). Sebagai upaya untuk menguji hipotesis pada data statistik parametrik tersebut dapat digunakan uji-t (t-test). Pengambilan keputusannya yaitu apabila nilai sig. $<\alpha$, dengan $\alpha=0,05$ maka $\mathrm{H}_{0}$ ditolak atau $\mathrm{H}_{1}$ diterima.

2) Uji statistik non-parametrik

Jika distribusi datanya tidak memenuhi persyaratan uji paramerik yaitu data terdistribusi tidak normal maka pengujian hipotesis dilakukan dengan uji statistik non-parametrik. Uji statistik non-parametrik yang digunakan jika asumsi parametrik tidak terpenuhi untuk sampel independen adalah uji Mann-Whitney $U$. Pengambilan keputusannya yaitu apabila nilai sig. $<\alpha$, dengan $\alpha=0,05$ maka $\mathrm{H}_{0}$ ditolak atau $\mathrm{H}_{1}$ diterima.

Adapun hipotesis penelitian ini adalah:

$\mathrm{H}_{0}$ : Tidak terdapat pengaruh yang signifikan karena adanya penerapan pembelajaran levels of inquiry terhadap kemampuan literasi sains siswa kelas $\mathrm{X}$ pada materi hukum Archimedes di SMA Negeri 1 Baradatu.

$\mathrm{H}_{1}$ : Terdapat pengaruh yang signifikan karena adanya penerapan pembelajaran levels of inquiry terhadap kemampuan literasi sains siswa kelas $\mathrm{X}$ pada materi hukum Archimedes di SMA Negeri 1 Baradatu.

\section{Hasil dan Pembahasan}

\subsection{Keterlaksanaan Pembelajaran LOI}

Keterlaksanaan pembelajaran LOI yang diperoleh dari setiap kegiatan pembelajaran di kelas eksperimen diobservasi oleh seorang observer. Berikut data hasil keterlaksanaan aktivitas pendidik dan peserta didik pada Gambar 1 dan Gambar 2. 


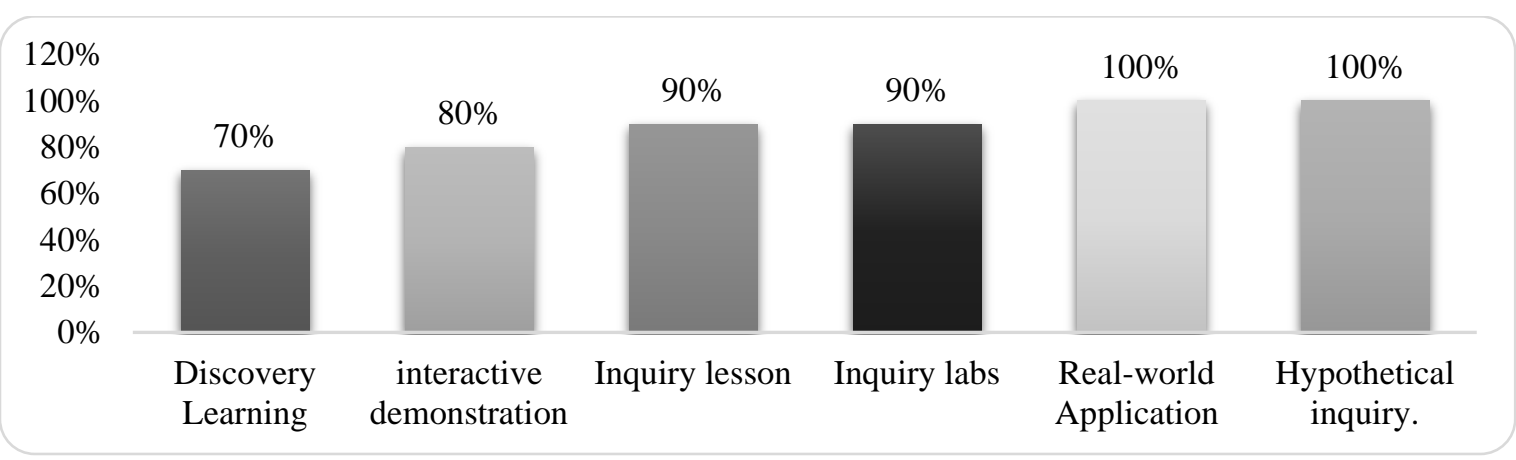

Gambar 1. Diagram Batang Keterlaksanaan Aktivitas Pendidik

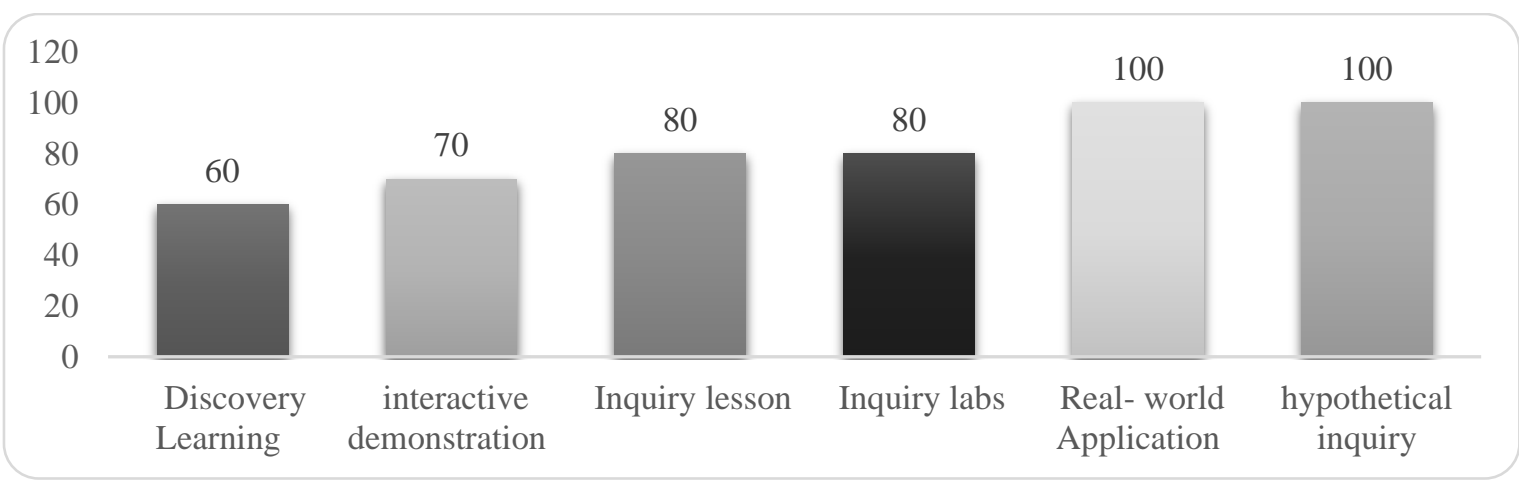

Gambar 2. Diagram Batang Keterlaksanaan Aktivitas Peserta Didik

Berdasarkan pemaparan diatas dapat dikatakan bahwa keterlaksanaan pembelajaran levels of inquiry dari hasil observasi oleh observer hampir seluruh aktivitas terlaksana. Data yang dihasilkan $80 \%$ untuk rata-rata keterlaksanaan aktivitas pendidik dengan kategori seluruh kegiatan terlaksana dari dua puluh dua tahapan aktivitas pendidik, sedangkan sebesar $72,5 \%$ untuk rata-rata keterlaksanaan aktivitas peserta didik dengan kategori seluruh kegiatan terlaksana dari dua puluh dua tahapan aktifitas peserta didik.

Kegiatan-kegiatan yang dilakukan pada setiap tahapan dari model pembelajaran LOI untuk meningkatkan literasi sains adalah:

\section{a. Tahap Discovery Learning}

Siswa mengamati berbagai gejala atau fenomena penerapan hukum Archimedes di sekitar mereka mengenai topik/permasalahan, menjelaskan persamaan dan perbedaan yang mereka amati dari fenomena atau gejala tersebut. Siswa mengembangkan konsep berdasarkan pengalaman langsung (berfokus pada keterlibatan aktif untuk membangun pengetahuan). Selama membangun pengetahuan, siswa mengidentifikasi berbagai jawaban yang mungkin melalui kegiatan tanya jawab dan diskusi terkait suatu konsep atau prinsip yang ditemukan. Setelah itu, siswa mengidentifikasi dan mengomunikasikan 
kesimpulan yang mereka peroleh melalui diskusi kelompok untuk disampaikan di kelas. Pada tahap ini, peneliti menemukan bahwa aspek literasi sains yang berkembang adalah aspek konteks yaitu pada sub aspek personal dan aspek pengetahuan pada sub aspek konten.

\section{b. Tahap Interactive Demonstration}

Guru dibantu oleh siswa melakukan demonstrasi untuk menyelidiki kebenaran konsep dan prediksi siswa berkaitan dengan kegiatan sebelumnya pada tahap discovery learning. Siswa terlibat dalam penjelasan (memberikan alasan) dan pembuatan prediksi. Siswa menguji prediksi mereka melalui pengamatan saat kegiatan demonstrasi. Siswa mengumpulkan data-data, menginterpretasikan dan mendiskusikannya dengan teman kelompok. Selama kegiatan tersebut, siswa berusaha menerapkan prinsip-prinsip yang telah mereka temukan untuk memprediksi dan menjelaskan hasil pengamatan dari kegiatan demonstrasi. Setelah itu setiap kelompok menyampaikan hasil diskusi mereka di kelas. Pada tahap ini, peneliti menemukan bahwa aspek literasi sains yang berkembang adalah aspek kompetensi pada semua sub aspek dan aspek pengetahuan pada sub aspek prosedur.

c. Tahap Inquiry Lesson

Siswa mengidentifikasikan variabel-variabel penyelidikan (percobaan) berkaitan dengan permasalahan yang mereka hadapi hukum Archimedes. Kemudian siswa memprediksi dan mengajukan hipotesis terkait hubungan variabel-variabel. Ketika melakukan kegiatan tersebut, siswa mengidentifikasi berbagai jawaban yang mungkin melalui kegiatan tanya jawab dan diskusi terkait suatu konsep atau prinsip yang telah ditemukan. Siswa melakukan diskusi kelompok untuk merencanakan percobaan untuk menyelidiki hubungan antara variabel-variabel tersebut. Kegiatan merencanakan percobaan yang dilakukan, menuntut siswa untuk merumuskan berbagai alternatif solusi pemecahan masalah. Pada tahap ini, peneliti menemukan bahwa aspek literasi sains yang berkembang adalah hanya pada aspek kompetensi pada semua sub aspek.

d. Tahap Inquiry Laboratory

Siswa melakukan percobaan kuantitatif untuk merumuskan hubungan antara variabelvariabel penyelidikan hukum Archimedes. Siswa melakukan serangkaian pengamatan dan pengukuran variabel-variabel untuk menetapkan hukum empiris. Siswa mengumpulkan data-data yang mereka peroleh, menginterpretasikan, menganalisis dan 
mendiskusikannya dengan teman kelompok. Dalam melakukan percobaan, siswa menerapkan konsep dan prinsip yang telah mereka miliki untuk memecahkan permasalahan. Selain itu, dalam melakukan percobaan tersebut, beberapa alternatif pemecahan masalah (solusi) dicoba oleh siswa untuk membuktikan hipotesis yang telah mereka ajukan. Tak jarang, siswa mengalami kegagalan dalam melakukan pembuktian, sehingga melatih siswa untuk mengevaluasi langkah percobaan yang dilakukan dan belajar dari kesalahan. Pada tahap ini, peneliti menemukan bahwa aspek literasi sains yang berkembang adalah pada aspek kompetensi pada semua sub aspek, aspek konteks pada sub aspek personal, dam aspek pengetahuan pada semua sub aspek.

\subsection{Analisis Uji Statistik Kemampuan Literasi Sains Siswa}

Di bawah ini disajikan deskripsi data dan hasil uji statistik pretest dan posttest (uji hipotesis) kemampuan literasi sains siswa pada kelas kontrol dan kelas eksperimen.

Tabel 5. Deskripsi data pretest dan posttest kelas eksperimen dan kelas kontrol

\begin{tabular}{cccccccc}
\hline \multirow{2}{*}{ No Distribusi Frekuensi } & \multicolumn{3}{c}{ Eksperimen } & \multicolumn{3}{c}{ Kontrol } \\
\cline { 3 - 8 } & & Pretest & Posttest & $\langle\mathbf{g}\rangle$ & Pretest & Posttest & $\langle$ g $\rangle$ \\
\hline 1 & Nilai Tertinggi & 75 & 100 & & 75 & 75 & \\
2 & Nilai Terendah & 0 & 50 & 0,54 & 0 & 12,50 & 0,18 \\
3 & Mean & 40,97 & 72,91 & (Sedang) & 37,50 & 48,95 & (Rendah) \\
4 & Median & 37,50 & 75 & & 37,50 & 50 & \\
5 & Standar Deviasi & 25,63 & 15,08 & & 25,87 & 19,22 & \\
\hline
\end{tabular}

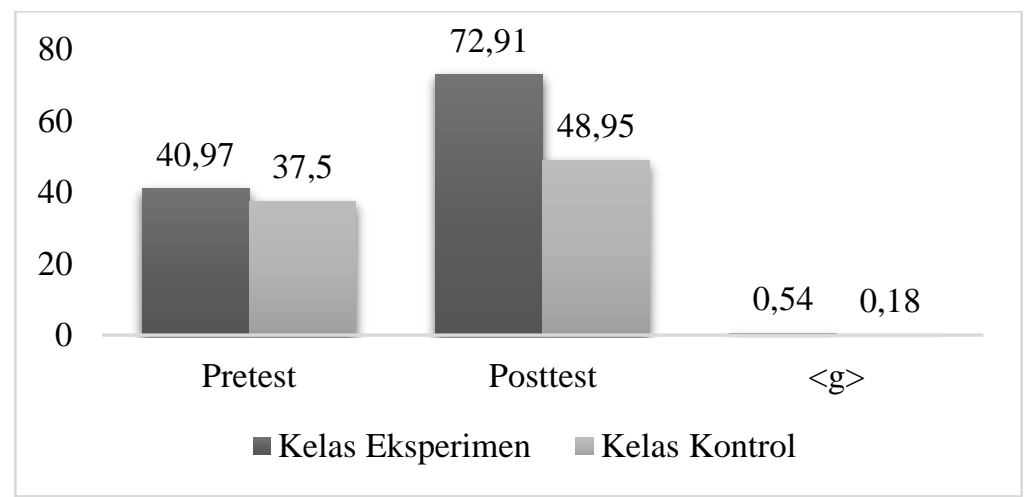

Gambar 3. Skor Rata-Rata Pretest, Posttest, dan <g> Kemampuan Literasi Sains Siswa Kelas Eksperimen dan Kelas Kontrol

Dari Gambar 3 terlihat jelas perbedaan peningkatan literasi sains antara kelas eksperimen dan kelas kontrol. Skor rata-rata pretest yang diperoleh siswa pada kelas eksperimen sebesar 40,97 dan siswa pada kelas kontrol sebesar 37,5. Skor rata-rata posttest yang diperoleh siswa pada kelas eksperimen sebesar 72,91 dan siswa pada kelas kontrol sebesar 48,95. Perolehan skor rata-rata $N$-gain $<\mathrm{g}>$ untuk kelas eksperimen sebesar 0,54 dan 
kelas kontrol sebesar 0,18. Perolehan skor rata-rata $N$-gain $\langle\mathrm{g}>$ untuk kelas eksperimen termasuk kategori "sedang" sedangkan untuk kelas kontrol termasuk kategori "rendah".

Pengujian hipotesis peningkatan literasi sains dilakukan melalui pengolahan data $\mathrm{N}$ gain untuk setiap siswa. Langkah-langkah yang dilakukan untuk pengujian hipotesis terdiri dari uji normalitas menggunakan uji Shapiro-Wilk, uji homogenitas menggunakan uji Lavene, dan uji beda rata-rata menggunakan uji t. Adapun hasil pengujian hipotesis peningkatan literasi sains disajikan pada Tabel 6, Tabel 7, dan Tabel 8.

Tabel 6. Hasil uji normalitas pretest dan posttest

\begin{tabular}{ccccc}
\hline \multirow{2}{*}{ Statistik } & \multicolumn{2}{c}{ Eksperimen } & \multicolumn{2}{c}{ Kontrol } \\
\cline { 2 - 5 } & Pretest & Posttest & Pretest & Posttest \\
\hline Sig. & 0,311 & 0,274 & 0,494 & 0,299 \\
Uji Kolmogorov-Smirnov & Sig. $\geq 0,05$ & Sig. $\geq 0,05$ & Sig. $\geq 0,05$ & Sig. $\geq 0,05$ \\
Kesimpulan & Normal & Normal & Normal & Normal \\
\hline
\end{tabular}

Tabel 7. Hasil uji homogeritas pretest dan posttest

\begin{tabular}{ccc}
\hline Statistik & Pretest Kelas Eksperimen dan Kelas & $\begin{array}{c}\text { Posttest Kelas Eksperimen dan Kelas } \\
\text { Kontrol }\end{array}$ \\
\hline Sig. & 0,892 & 2,418 \\
Uji Levene's & Sig. $\geq 0,05$ & Sig. $\geq 0,05$ \\
Kesimpulan & Homogen & Homogen \\
\hline
\end{tabular}

Tabel 8. Hasil uji uji hipotesiss pretest dan posttest

\begin{tabular}{ccc}
\hline Uji t-Test & Pretest & Posttest \\
\hline Kriteria & Sig.(2-tailed) $\geq 0,05$ & Sig.(2-tailed) $<0,05$ \\
Sig.(2-tailed) & 0,569 & 0,000 \\
Keputusan & $\mathrm{H}_{\mathrm{o}}$ diterima & $\mathrm{H}_{1}$ diterima \\
\hline
\end{tabular}

Berdasarkan hasil perhitungan, Kelas kontrol dan Kelas eksperimen memiliki kemampuan literasi sains yang hampir sama ketika sebelum diberikan perlakuan. Setelah pembelajaran dengan penerapan $L O I$ selesai pada kelas eksperimen dan pembelajaran dengan metode konvensional pada kontrol, diberikan kembali tes kemampuan literasi sains (posttest). Hal ini dilakukan untuk mengetahui pengaruh pembelajaran $L O I$ terhadap kemampuan literasi sains siswa pada kelas eksperimen. Tes yang diberikan sama halnya dengan tes yang diberikan sebelum pembelajaran. Berdasarkan Tabel 5 rata-rata nilai posttest kelas kontrol lebih kecil dibandingkan dengan kelas eksperimen dengan $N$-gain sebesar 0,54 pada kelas eksperimen dan 0,18 pada kelas kontrol. Uji hipotesis menunjukkan terdapat perbedaan yang signifikan antara hasil posttest kemampuan literasi sains kelas kontrol dengan kelas 
eksperimen, dengan nilai t-hitung sebesar 0.00 (Sig.(2-tailed) < 0,05). Hal ini menunjukkan bahwa pembelajaran inkuiri dapat meningkatkan kemampuan literasi sains siswa pada kelas eksperimen dibandingkan dengan kelas kontrol yang menggunakan pembelajaran konvensional. Sesuai dengan penelitian sebelumnya, bahwa hasil analisis data menunjukkan pembelajaran menggunakan levels of inquiry dapat meningkatkan literasi sains siswa (Dahtiar, 2015; Fatmawati \& Utari, 2015).

Berdasarkan hasil uji hipotesis di atas metode LOI memberikan pengaruh yang lebih baik dibandingkan dengan metode pembelajaran konvensional. (Fatmawati \& Utari, 2015). Salah satu alasan yang membuat pembelajaran LOI lebih baik dibandingkan dengan pembelajaran konvensional adalah dapat dilihat dari segi kelebihan, LOI memberikan kesempatan kepada siswa untuk mengembangkan pemikirannya dengan cara melibatkan kognitifnya untuk berpikir selama kegiatan pembelajaran. Kelebihan metode inkuiri diantaranya mengembangkan bakat, seperti bakat akademik, kreatif, dan sosial, pengajaran menjadi terpusat pada siswa, dan metode inkuiri dapat menghindari siswa dari belajar dengan hafalan. (Asyhari \& Hartati, 2015; Asyhari, Sunarno, \& Sarwanto, 2014; Anam, 2016).

Penerapan LOI dengan tahapan-tahapan inkuiri memiliki kontribusi yang besar dalam meningkatkan kemampuan literasi sains siswa (Triwijayanti, Loekmono, \& Sutriyono, 2015; Arief \& Utari, 2015; Fatmawati \& Utari, 2015). Peningkatan kemampuan literasi sains terjadi karena dalam penerapan levels of inquiry (tahapan-tahapan inkuiri) pada pembelajaran fisika siswa dilatih sesuai dengan tuntutan yang ada dalam literasi sains yaitu meliputi domain kompetensi dan domain pengetahuan. Hal tersebut dapat terlihat selama proses penerapan LOI pada pembelajaran fisika. (Setiyawati \& Kuswanto, 2015)

\subsection{Temuan Penelitian}

Berdasarkan pemaparan hasil penelitian di atas, juga diperoleh temuan bahwa penerapan LOI mempunyai kontribusi paling besar dalam meningkatkan aspek pengetahuan prosedural jika dibandingkan dengan pengetahuan konten dan pengetahuan epistemik. Hal ini terjadi karena pembelajaran dengan menggunakan LOI lebih menekankan pada aspek kegiatan penyelidikan ilmiah. Peserta didik dilatih untuk merancang dan mengevaluasi penyelidikan ilmiah. Sedangkan peningkatan literasi sains peserta didik yang paling rendah pada domain pengetahuan adalah pada pengetahuan konten. Rendahnya peningkatan literasi sains peserta didik pada domain pengetahuan konten jika dibandingkan dengan domain pengetahuan epistemik dan domain pengetahuan prosedural, disebabkan kurang sempurnanya pelaksanaan 
LOI pada tahap discovery learning. Seperti yang telah dijelaskan sebelumnya, bahwa pada tahap discovery learning peserta didik masih belum bisa menggunakan pengetahuan kontennya untuk menjelaskan fenomena ilmiah dengan sempurna. Selain hal itu karena karakteristik soal pada domain pengetahuan konten cenderung bersifat analisis.

Rendahnya peningkatan pengetahuan konten peserta didik dapat diatasi dengan fasilitas pemberian bahan bacaan yang bersifat ilmiah dan mendalam tentang materi yang akan diajarkan. Penggunaan bahan bacaan dari berbagai sumber misalnya artikel, buku ataupun jurnal-jurnal ilmiah akan dapat memberikan tambahan pengetahuan konten bagi peserta didik. Dengan diberikannya artikel ataupun jurnal kepada peserta didik dapat memperkaya pengetahuan kontennya, sehingga pada tahap discovery learning peserta didik dapat menggunakan pengetahuan kontennya untuk menjelaskan fenomena ilmiah yang diberikan pendidik dengan lebih baik.

Hasil perhitungan angket yang diisi oleh siswa, 88,89\% siswa yang menyatakan dapat memahami materi, meningkatkan siswa lebih aktif, dalam proses pembelajaran yang diperoleh dari data angket 36 siswa. Sedangkan 83,34\% siswa yang menyatakan senang dan tertarik serta dapat meningkatkan kemampuan literasi sains dan setuju dengan model pembelajaran Inkuiri diterapkan dalam kegiatan pembelajaran fisika lainnya yang diperoleh dari data angket 36 siswa.

Pada saat pra-penelitian masih banyaknya siswa yang belum berperan aktif dalam proses pembelajaran, setelah peneliti melalukan penelitian dengan menggunakan model pembelajaran Inkuiri terhadap kemampuan literasi sains didapatkan bahwa siswa telah berperan aktif dalam proses pembelajaran.

\section{Simpulan}

Berdasarkan hasil dan pembahasan, maka dapat disimpulkan bahwa terdapat pengaruh yang signifikan karena adanya penerapan LOI (levels of inquiry) terhadap kemampuan literasi sains siswa pada kelas eksperimen dibandingkan dengan kelas kontrol yang menggunakan pembelajaran konvensional.

\section{Daftar Pustaka}

Anam, K. (2016). Pembelajaran berbasis inkuiri: metode dan aplikasi. Yogyakarta: Pustaka Pelajar. 
Arief, M. K., \& Utari, S. (2015). Implementation of levels of inquiry on science learning to improve junior high school students' scientific literacy. Jurnal Pendidikan Fisika Indonesia, 11(2), 117-125. DOI: 10.15294/jpfi.v11i2.4233

Arikunto, S. (2013). Dasar-dasar evaluasi pendidikan (edisi 2). Jakarta: Bumi Aksara.

Asyhari, A. (2017). Literasi sains berbasis nilai-nilai islam dan budaya Indonesia. Jurnal Ilmiah Pendidikan Fisika Al-Biruni, 6(1), 137-148. DOI: 10.24042/jpifalbiruni.v6i1.1584

Asyhari, A., \& Hartati, R. (2015). Implementasi pembelajaran fisika SMA berbasis inkuiri terbimbing terintegrasi pendidikan karakter untuk meningkatkan hasil belajar siswa pada materi cahaya dan optika. Jurnal Ilmiah Pendidikan Fisika Al-Biruni, 4(1), 37-49. DOI: 10.24042/jpifalbiruni.v4i1.79

Asyhari, A., \& Hartati, R. (2015). Profil peningkatan kemampuan literasi sains siswa melalui pembelajaran saintifik. Jurnal Ilmiah Pendidikan Fisika Al-Biruni, 4(2), 179-191. DOI: 10.24042/jpifalbiruni.v4i2.91

Asyhari, A., Sunarno, W., \& Sarwanto, S. (2014). Pengembangan perangkat pembelajaran fisika SMA berbasis inkuiri terbimbing terintegrasi pendidikan karakter. Jurnal inkuiri, 3(1), 62-75. Available online: https://journal.uny.ac.id/index.php/jitp/article/view/13435

Bybee, R., \& McCrae, B. (2011). Scientific literacy and student attitudes: perspectives from PISA 2006 science. International Journal of Science Education, 33(1), 7-26. DOI: 10.1080/09500693.2010.518644

Carl, N., Cofnas, N., \& Woodley of Menie, M. A. (2016). Scientific literacy, optimism about science and conservatism. Personality and Individual Differences, 94(2016), 299-302. DOI: 10.1016/j.paid.2016.01.046

Dahtiar, A. (2015). Pembelajaran levels of inquiry (LOI) untuk meningkatkan literasi sains siswa pada konteks energi alternatif. Bandung: Universitas Pendidikan Indonesia.

Fatimah, F., Susilo, H., \& Diantoro, M. (2016). Keterampilam proses sains siswa kelas VII dengan pembelajaran model levels of inquiry. Jurnal Pendidikan: Teori, Penelitian, dan Pengembangan, 1(9), 1706-1712. DOI: 10.17977/jp.v1i9.6829

Fatmawati, I. N., \& Utari, S. (2015). Penerapan levels of inquiry untuk meningkatkan literasi sains siswa SMP tema limbah dan upaya penanggulangannya. Edusains, 7(2), 151-159. DOI: $10.15408 /$ es.v7i2.1750

Fraenkel, \& Wallen. (2009). How to design and evaluate research in education (seventh edition). New York: McGraw-Hill Higher Education.

Hardianti, T., \& Kuswanto, H. (2017). Difference among levels of inquiry: process skills improvement at senior high school in Indonesia. International Journal of Instruction, 10(2), 119-130. DOI: 10.12973/iji.2017.1028a

Hartini, R. I. (2017). Penggunaan levels of inquiry dalam meningkatkan keterampilan proses sains siswa. JIPF: Jurnal Ilmu Pendidikan Fisika, 2(1), 19-24. DOI: 10.26737/jipf.v2i1.200

Muslim. (2014). Pengembangan program perkuliahan fisika sekolah berorientasi kemampuan berargumentasi calon guru fisika. Bandung: Sekolah Pascasarjana, Universitas Pendidikan Indonesia.

OECD. (2016). PISA 2015 Assessment and analytical framework: science, reading, mathematic and financial literacy. Paris: OECD Publishing. DOI:10.1787/9789264255425en 
Ramdan, S., \& Hamidah, I. (2015). Peningkatan keterampilan proses sains siswa SMP melalui penerapan levels of inquiry dalam pembelajaran IPA. Edusains, 7(2), 105-113. DOI: 10.15408/es.v7i2.1782

Setiyawati, S. F., \& Kuswanto, H. (2015). Pengembangan buku pedoman guru pada pembelajaran fisika SMA menggunakan model problem solving level inkuiri. Jurnal Inovasi Pembelajaran IPA, 1(2), 225-236. DOI: 10.21831/jipi.v1i2.7509

Toharudin. (2011). Membangun literasi sains peserta didik. Bandung: Humaniora.

Triwijayanti, N., Loekmono, J. L., \& Sutriyono, S. (2015). Perbedaan prestasi belajar fisika antara peserta didik yang diajar dengan metode levels of inqury learning cycle dan metode ceramah. Jurnal Manajemen Pendidikan, 2(1), 110-125. DOI: 10.24246/j.jk.2015.v2.i1.p110-125

Wenning, C. J. (2005). Levels of inquiry: hierarchies of pedagogical practices and inquiry Processes. Journal of Physics Teacher Education Online, 2(3), 3-11. Available online: http://www2.phy.ilstu.edu/ wenning/jpteo/issues/feb2005.html

Wenning, C. J. (2006). A Framework for teaching the nature of science. Journal of Physics Teacher Education Online, 3(3), 11-20. Available online: http://www2.phy.ilstu.edu/ wenning/jpteo/issues/mar2006.html

Wenning, C. J. (2010). Levels of inquiry: using inquiry spectrum learning sequences to teach science. Journal of Physics Teacher Education Online, 5(4), 11-20. Available online: http://www2.phy.ilstu.edu/ wenning/jpteo/issues/sum2010.html

Wenning, C. J. (2011). The levels of inquiry model of science teaching. Journal of Physics Teacher Education Online, 6(2), 9-16. Available online: http://www2.phy.ilstu.edu/ wenning/jpteo/issues/sum2011.html 